\title{
MENYONGSONG REFORMASI BIROKRASI TAHAP KEDUA MELALUI PENINGKATAN KUALITAS PELAYANAN PUBLIK ${ }^{1}$
}

\author{
Meiliana \\ Pusat Kajian dan Pendidikan dan Pelatihan Aparatur III Lembaga \\ Administrasi Negara \\ JI. H.M. Ardans, SH. (Ring Road III) Samarinda.
}

\begin{abstract}
Improved governance at this time is encouraged through the implementation of bureaucratic reforms program that has entered the second stage (2010-2014). One considerable area of change in the bureaucratic reform that needs to be improved is public services, especially in the current era of regional autonomy nowadays where the regions have opportunity to innovate, be creative, and create the best model to achieve improved quality of service to the community. One important effort suggested by the author to improve the quality of public services is to do public service management reform, to fulfill completeness of organizational development, and implementation of zero management in public service activities. If this can be implemented, it is expected that people's satisfaction is achieved, which together will show the better performance of the government, and in the aggregate will show the successful implementation of bureaucratic reforms.
\end{abstract}

Keywords : Bureaucratic reform, public service, regional autonomy

Intisari

Perbaikan tata kelola pemerintahan yang saat ini digalakkan melalui pelaksanaan program reformasi birokrasi sudah memasuki tahapan atau gelombang kedua (2010-2014). Salah satu area perubahan reformasi birokrasi yang cukup penting untuk ditingkatkan adalah pelayanan publik, terutama di era otonomi daerah saat ini yang memberikan kesempatan kepada daerah untuk berinovasi, berkreasi, dan menciptakan model terbaik demi pencapaian peningkatan kualitas pelayanan kepada masyarakat. Upaya penting yang disarankan oleh penulis untuk meningkatkan kualitas pelayanan publik adalah dengan melakukan pembenahan manajemen pelayanan publik, memenuhi kelengkapan pengembangan organisasi, serta penerapan manajemen zero dalam aktivitas pelayanan publik. Jika hal ini mampu dilaksanakan, maka diharapkan kepuasan masyarakat akan tercapai, yang secara bersinergi menunjukkan kinerja pemerintahan yang semakin baik, dan

$\overline{1}$ Naskah diterima: 10 Januari 2011, revisi: 13 Maret 2011. 
secara agregat menunjukkan keberhasilan pelaksanaan reformasi birokrasi.

\section{Kata Kunci : Reformasi Birokrasi, Pelayanan Publik, Otonomi Daerah}

\section{A. PENDAHULUAN}

Dalam konsep negara kesejahteraan (welfare state), tugas utama pemerintah adalah memberikan pelayanan umum atau mengusahakan kesejahteraan bagi warga negaranya, disamping memberikan perlindungan bagi warga negaranya. Tugas pemerintah tersebut juga tertuang secara tegas dalam alenia ke-empat pembukaan UUD 1945 yang berbunyi "melindungi segenap bangsa Indonesia, memajukan kesejahteraan umum, mencerdaskan kehidupan bangsa, dan ikut melaksanakan ketertiban dunia yang berdasarkan kemerdekaan, perdamaian abadi dan keadilan sosial". Hingga saat ini, pelaksanaan tugas-tugas pemerintah tersebut telah berjalan dan berupaya diwujudkan, namun masih belum optimal terlihat hasilnya. Oleh karenanya, melalui program reformasi birokrasi yang diluncurkan, diharapkan dapat menjadi akselerator bagi pelaksanaan tugas-tugas pemerintahan.

Reformasi birokrasi adalah kancah dan wahana untuk optimalisasi perubahan penyelenggaraan pemerintahan, yang saat ini masih dikesankan lamban, berbelit-belit, tidak kompeten, dan koruptif. Setidaknya terdapat 4 (empat) tuntutan yang mewarnai kebutuhan akan reformasi birokrasi saat ini, dan tuntutan ini perlu dipahami secara mendasar oleh seluruh penyelenggara pemerintahan :

\section{Tuntutan Daya Saing}

Era Globalisasi yang semakin maju dan berkembang pesat menuntut daya tanggap dan adaptif pemerintah agar mampu bersaing dengan perkembangan negaranegara maju dan modern. Kondisi saat ini juga menunjukkan nilai Indeks Pembangunan Manusia (IPM) Indonesia masih tergolong rendah, yakni urutan 111 dari 182 negara. Penggunaan dan penguasaan ICT dalam pemberian pelayanan (e-development) adalah salah satu hal mutlak yang perlu dipenuhi agar proses pelayanan publik menjadi lebih cepat dan efisien. Selain itu, kapasitas aparatur pemerintah juga dituntut mampu bekerja lebih profesional dan unggul.

2. Tuntutan Masyarakat

Era demokrasi dan keterbukaan saat ini, telah memunculkan banyaknya pengaduan dan kritikan dari masyarakat yang menginginkan kualitas pelayanan publik dan kualitas birokrasi yang makin baik dari hari ke hari. Peningkatan peran dan partisipasi masyarakat dalam pengambilan keputusan publik juga menjadi harapan untuk menjamin terlaksananya tatakelola pemerintahan yang baik.

3. Tuntutan Hukum

Pelaksanaan dan penerapan asasasas umum kepemerintahan yang baik (algemene beginselen van behoorlijk bestuur) adalah harapan 
dari semua ketentuan peraturan perundangan yang diterbitkan. Masih banyaknya kasus KKN, pungutan liar (pungli), pejabat yang bertindak melampui kewenangan yang dimiliki adalah beberapa pelanggaran hukum yang perlu ditata kembali. Keseluruhan peraturan perundangan yang berlaku juga mengamanatkan kepada pemerintah atas pencapaian dan peningkatan kesejahteraan masyarakat, dan hal ini tidak boleh diingkari dengan kepentingankepentingan pribadi dan golongan tertentu.

\section{Tuntutan Ekonomi}

Aktivitas dunia usaha yang terus menggeliat dan mengalir kencang ke daerah tentunya perlu dibarengi dengan penciptaan suasana yang kondusif, serta fasilitas dan kemudahan berinvestasi yang diberikan oleh pemerintah. Prosedur; persyaratan; dan alur perizinan, investasi, atau penanaman modal masih banyak dikeluhkan dan perlu segera dibenahi. Pemerintah tentunya sangat berharap banyaknya investor yang menanamkan modalnya di daerah, sebab perkembangan aktivitas dunia usaha akan menggairahkan pertumbuhan ekonomi daerah dan secara ekuivalen dapat meningkatkan pertumbuhan Pendapatan Asli Daerah (PAD).

Salah satu agenda utama pembangunan nasional tahun 2010 2014 adalah melakukan perbaikan tata kelola pemerintahan. Oleh karenanya perlu segera diakselerasi dan dipacu secara terarah dan terukur terhadap implementasi reformasi birokrasi yang berbasiskan kinerja, mengingat data dan fakta aktual saat ini menunjukkan hal tersebut perlu segera dibenahi. Berdasarkan hasil survey dari Political and Economic Risk Consultancy (PERC) tahun 2010, Indonesia tercatat sebagai negara nomor 2 (dua) dengan sistem birokrasi terburuk di Asia, Indonesia juga masih dikategorikan sebagai negara terkorup di Asia Pasifik. Sedangkan peringkat kemudahan berbisnis tahun 2010, Indonesia menempati posisi ke-122 dari 183 negara. Skor integritas pelayanan publik yang dikeluarkan KPK tahun 2009 juga menunjukkan penurunan, baik instansi pusat maupun unit pelayanan publik di daerah, sedangkan opini BPK atas laporan keuangan pemerintah pusat dan pemerintah daerah sebagian besar masih dikategorikan disclaimer. Berkaca dari kondisi tersebut, perlu upaya yang lebih keras dan sistematis untuk memperbaiki tata kelola pemerintahan ini, sebab pembangunan birokrasi yang kuat merupakan elemen penting untuk menjaga agar kelangsungan pembangunan tetap berkelanjutan.

Dari 10 tantangan pembangunan nasional 2010-2014 sesuai yang termuat dalam Rencana Pembangunan Jangka Menengah Nasional (RPJMN) tahun 2010-2014, pencapaian tata kelola pemerintahan yang baik melalui program reformasi birokrasi juga menjadi salah satu tantangan utama. Disebutkan bahwa pada saat ini, kualitas birokrasi Indonesia perlu ditingkatkan untuk menghadapi persaingan di era globalisasi. Ekonomi biaya tinggi yang terjadi hingga dewasa ini tidak terlepas dari rendahnya 
kualitas birokrasi. Oleh karena itu, keberhasilan reformasi birokrasi merupakan kunci utama yang membawa Indonesia dalam kancah persaingan di pasar global dan meningkatkan daya saing nasional.

Reformasi birokrasi sebagai upaya perbaikan tata kelola pemerintahan juga menjadi agenda utama dan prioritas pembangunan nasional tahun 2010-2014, perbaikan tata kelola pemerintahan yang baik menjadi isu yang penting dalam konteks nasional dan internasional. Krisis ekonomi yang lalu tidak terlepas dari buruknya tata kelola pemerintahan, baik di sektor pemerintahan maupun swasta. Krisis keuangan global, juga tidak terlepas dari masalah ini. Oleh karena itu, negara-negara yang tergabung dalam G-20 sepakat untuk menempatkan perbaikan tatakelola pemerintahan menjadi salah satu agenda perbaikan untuk mencegah krisis berulang. Wujud dari perbaikan tata kelola pemerintahan ini antara lain dapat dilihat dari penurunan tingkat korupsi, perbaikan pelayanan publik, dan pengurangan ekonomi biaya tinggi yang menghambat investasi.

Pembangunan birokrasi yang kuat merupakan elemen penting untuk menjaga agar kelangsungan pembangunan tetap berkelanjutan. Untuk itu, reformasi birokrasi akan dilaksanakan di seluruh kementerian/ lembaga untuk selanjutnya diteruskan di Pemerintah Daerah. Selanjutnya, dalam penyusunan perencanaan dan anggaran, akan diterapkan sistem anggaran berbasis kinerja secara menyeluruh. Reformasi ini diharapkan dapat membuahkan hasil yang positif khususnya dalam perbaikan kualitas pelayanan publik, efektivitas dan akuntabilitas kegiatan kementerian/ lembaga dan penanggulangan korupsi.

Secara mendasar reformasi birokrasi akan menyebabkan terjadinya perubahan dalam tubuh organisasi, dan perubahan tersebut harus mampu diadaptasi oleh seluruh aparatur yang ada. Terlebih adanya program quick wins yang menuntut adanya kecepatan dalam pengaruh, hasil, dan dampak dari reformasi birokrasi yang dilaksanakan. Perubahan dalam organisasi menurut Rhenald Kasali (2007), ada 2 (dua) jenis yaitu dapat berupa, (1) perubahan operasional, yaitu perubahan-perubahan kecil yang bersifat parsial dan umumnya tidak memberikan dampak yang begitu luas bagi unit-unit lain dalam organisasi, (2) perubahan strategis, yang berdampak luas dan memerlukan koordinasi dan dukungan dari unit-unit terkait, atau bahkan seluruh komponen organisai. Perubahan strategis tersebut antara lain:

- Perubahan budaya dan nilai-nilai dasar organisasi. Perubahan budaya pada dasarnya harus dikaitkan dengan strategi dan lingkungan organisasi. Sedangkan perubahan nilai-nilai dan norma-norma membutuhkan dukungan semua pihak dan memerlukan cukup waktu;

- Perubahan arah/lokus organisasi. Melakukan restrukturisasi orientasi organisasi guna terkait perkembangan lingkungan internal dan eksternal organisasi;

- Perubahan cara kerja, untuk meningkatkan efisiensi, 
peningkatan penghasilan (revenue), atau pemakaian sumberdaya.

Langkah-langkah yang disebutkan di atas, akan dipercepat dengan memantapkan dan memperluas program percepatan reformasi birokrasi yang dikombinasikan dengan sejumlah program aksi lainnya seperti reformasi bidang hukum. Cakupan perbaikan dalam tata kelola pemerintahan tidak hanya terbatas pada sektor pemerintahan, tetapi juga meliputi sektor swasta termasuk pengelolaan BUMN. Untuk mendorong perbaikan tata kelola swasta, pemerintah akan mendorong lebih banyak perusahaan untuk mengubah statusnya menjadi perusahaan publik. Perubahan ini akan mendorong keterbukaan dan akuntabilitas publik dari sektor korporasi di Indonesia. Hal ini juga penting untuk mencegah kolusi, nepotisme, serta konflik kepentingan yang dapat mengganggu roda perekonomian.

Presiden Republik Indonesia, Dr. Susilo Bambang Yudhoyono dalam pidatonya tanggal 14 Agustus 2009 mengungkapkan penegasan kembali tekad pemerintah untuk melanjutkan misi sejarah bangsa Indonesia untuk lima tahun mendatang, yaitu melaksanakan reformasi gelombang kedua, termasuk reformasi birokrasi. Reformasi gelombang kedua bertujuan untuk membebaskan Indonesia dari dampak dan ekor krisis yang terjadi 10 tahun yang lalu. Sehingga pada tahun 2025 Indonesia diharapkan berada pada fase yang benar-benar bergerak menuju negara maju.
Harapan Presiden tersebut merupakan sebuah pertaruhan yang besar bagi segenap komponen penyelenggara negara karena jika gagal diwujudkan, reformasi birokrasi hanya akan menjadi sebuah kerangka konsep tidak aplikatif dan tidak berefek luas. Disisi lain menunjukkan ketidakmampuan birokrasi dalam menghadapi kompleksitas tantangan masa depan, antipati, dan kehilangan kepercayaan masyarakat yang berujung pada terhambatnya keberhasilan pembangunan nasional. Akan tetapi, jika reformasi birokrasi mampu berjalan berkesinambungan seperti yang disebutkan MENPAN-RB (2010) akan : (1) menjadikan negara yang memiliki most-improved bureaucracy; (2) meningkatkan mutu pelayanan kepada masyarakat; (3) mengurangi dan akhirnya menghilangkan setiap penyalahgunaan kewenangan publik; (4) meningkatkan mutu perumusan dan pelaksanaan kebijakan/program instansi; (5) meningkatkan efisiensi (biaya dan waktu); dan (6) menjadikan birokrasi Indonesia proaktif, efektif, dan antisipatif.

Refromasi gelombang kedua akan memantapkan tata kelola pemerintahan yang lebih baik melalui terobosan kinerja secara terpadu, penuh integritas, akuntabel, taat kepada hukum, dan transparan. Peningkatan kualitas pelayanan publik yang ditopang oleh efisiensi struktur pemerintah di pusat dan di daerah, kapasitas pegawai pemerintah yang memadai, dan data kependudukan yang baik. Oleh karena itu, substansi inti dari reformasi birokrasi dan tata kelola pemerintahan tahun 2010-2014 
sebagaimana tertuang dalam Buku I Prioritas Nasional pada Peraturan Presiden No. 5 Tahun 2010 adalah sebagai berikut:

1. Struktur

Konsolidasi struktural dan peningkatan kapasitas kementerian/ lembaga yang menangani aparatur negara yaitu Kementerian Negara Pendayagunaan Aparatur Negara dan Reformasi Birokrasi (KEMENPAN-RB), B adan Kepegawaian Negara (BKN), dan Lembaga Administrasi Negara (LAN) pada tahun 2010; restrukturisasi lembaga pemerintah lainnya, seperti di bidang keberdayaan UMKM, pengelolaan energi, pemanfaatan sumber daya kelautan, restrukturisasi BUMN, hingga pemanfaatan tanah dan penataan ruang bagi kepentingan rakyat banyak selambat-lambatnya tahun 2014;

2. Otonomi daerah

Penataan otonomi daerah melalui 1) penghentian / pembatas an pemekaran wilayah; 2) peningkatan efisiensi dan efektivitas penggunaan dana perimbangan daerah; dan 3) penyempurnaan pelaksanaan pemilihan kepala daerah;

3. Sumber daya manusia penyempurnaan pengelolaan PNS yang meliputi sistem rekrutmen, pendidikan, penempatan, promosi, dan mutasi PNS secara terpusat selambat-lambatnya tahun 2011;

4. Regulasi

Percepatan harmonisasi dan sinkronisasi peraturan perundangundangan di tingkat pusat dan daerah hingga tercapai keselarasan arah dalam implementasi pembangunan, di antaranya penyelesaian kajian 12.000 peraturan daerah selambatlambatnya tahun 2011;

5. Sinergi antara pusat dan daerah Penetapan dan penerapan sistem Indikator Kinerja Utama Pelayanan Publik yang selaras antara pemerintah pusat dan pemerintah daerah;

6. Penegakan Hukum

Peningkatan integrasi dan integritas penerapan dan penegakan hukum oleh seluruh lembaga dan aparat hukum;

7. Data Kependudukan: Penetapan Nomor Induk Kependudukan (NIK) dan pengembangan Sistem Informasi dan Administrasi Kependudukan (SIAK) dengan aplikasi pertama pada kartu tanda penduduk selambat-lambatnya pada tahun 2011.

\section{B. KUNCI KEBERHASILAN REFORMASI BIROKRASI}

Wakil Presiden Republik Indonesia, Boediono (2010) selaku ketua tim pengarah reformasi birokrasi mengatakan, ada empat kata kunci dalam pelaksanaan reformasi birokrasi yang tengah dilaksanakan pemerintah dewasa ini. Keempat kata kunci itu a d a lah, pelaks an a a n y a terdesentralisasi, diperkenankannya masing-masing memilih titik tolak dan menentukan kecepatannya, harus ada koordinasi secara sentral, dan outcome oriented. Pendekatan desentralisasi (decentralization approach) adalah, pemerintah akan mendesentralisasikan titik-titik reformasi pada masingmasing instansi, yakni kementerian, lembaga dan pemerintah daerah, baik provinsi, kabupaten maupun kota. 
Masing-masing isntansi mempunyai unit kerja sebagai ujung tombak reformasi birokrasi di instansinya.

Kata kunci kedua, didasarkan pada kenyataan bahwa birokrasi Indonesia memiliki kondisi kultural, geografis dan sebagainya yang berbeda satu sama lain, sehingga tidak mungkin satu blue print cocok untuk seluruh daerah dan instansi. Untuk itu, masingmasing instansi dengan kondisinya yang berbeda-beda dapat memulai pelaksanaan reformasi birokrasi di instansinya. Dengan kondisi obyektif masing-masing instansi, dapat menentukan titik tolak dan kecepatan yang berbeda, tetapi pelaksanaannya harus optimal. Kata kunci ketiga, adanya koordinasi secara sentral, sehingga Presiden melalui Keputusan Presiden menunjuk Wakil Presiden sebagai Ketua Tim Pengarah Reformasi Birokrasi. Selain Tim Pengarah, ada Tim Nasional reformasi Birokrasi, yang dipimpin oleh Menteri Negara PAN dan RB. Semua action plan reformasi birokrasi akan direview, dan harus mendapat persetujuan dari Ketua Tim Nasional.

Kata kunci terakhir, bahwa reformasi birokrasi harus berorientasi pada hasil (outcomes oriented). Meskipun proses pelaksanaan pelayanan dan kegiatan publik itu penting, tapi tetap harus mengedepankan hasil dan manfaat sebagai imbas dari kegiatan yang dilaksanakan. Dalam hal ini, beberapa indikator keberhasilan itu, harus bisa mengurangi penyimpangan/ penyelewengan serta tindakan korupsi. Selain itu harus menunjukkan adanya perbaikan pelayanan umum (publik), adanya support pelayanan untuk menciptakan kebijakan yang baik, serta tercapainya penghematan anggaran.

Saat ini, program reformasi birokrasi telah memasuki fase atau gelombang yang kedua yakni tahun 2010-2014. Perbedaan yang nyata antara reformasi birokrasi gelombang I (2004-2009) dan reformasi birokrasi gelombang II (2010-2014) adalah pada area perubahan yang concern pelaksanaannya. Jika sebelumnya area perubahannya adalah kelembagaan; budaya organisasi; ketatalaksanaan; regulasi-deregulasi; dan SDM Aparatur, maka saat ini area perubahannya adalah menguatkan budaya organisasi melalui perubahan pola pikir (mind-set) dan budaya kerja (culture-set) aparatur, dan ditambahkan dengan pengawasan (penyelenggaraan pemerintahan yang bersih dan bebas KKN), akuntabilitas, dan pelayanan publik (pelayanan prima sesuai kebutuhan dan harapan masyarakat). Terkait dengan tulisan ini, maka salah satu kunci keberhasilan reformasi birokrasi adalah dengan meningkatkan mutu pelayanan publik yang realisasinya sangat bergantung pada keberhasilan dalam pembangunan sistem layanan publik (tata laksana pemerintahan) modern, berbasis teknologi informasi dan teknologi lainnya; juga pengembangan organisasi dan manajemen pelayanan, dan sumberdaya manusia berbasis kinerja.

Arah kebijakan pendayagunaan aparatur negara dan percepatan pelaksanaan reformasi birokasi tahun 2010 - 2014 sebagaimana disebutkan MENPAN-RB (2010) adalah 
perbaikan tata kelola pemerintahan yang baik dan pelaksanaan reformasi birokrasi gelombang kedua, dan salah satu strategi dan arah kebijakan pembangunan didalamnya adalah peningkatan kualitas pelayanan publik. Melalui kebijakan tersebut diharapkan kualitas pelayanan publik menjadi lebih mudah, murah, cepat, tepat, transparan, akuntabel, tidak diskriminatif, dan bebas KKN. Berikut kerangka pikir pengembangan birokrasi yang profesional, inovatif, transparan, dan akuntabel melalui peningkatan kualitas pelayanan publik sebagai bagian dari reformasi birokrasi.

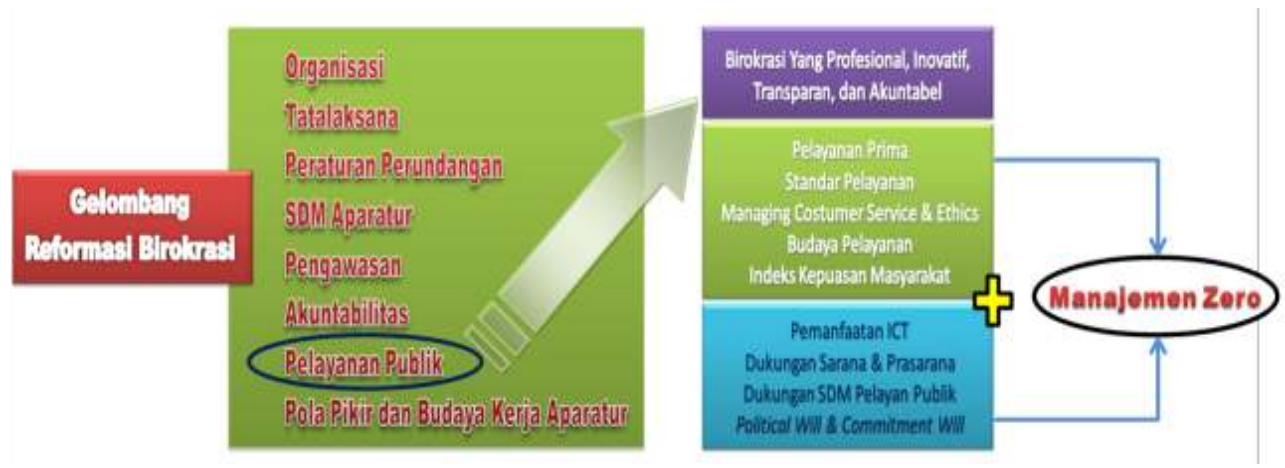

Gambar 1.

Peningkatan Kualitas Pelayanan Publik Dalam Rangka Optimalisasi Reformasi Birokrasi

Untuk mewujudkan pelayanan publik yang berkualitas, penulis menyarankan dilakukannya pembenahan manajemen pelayanan serta pemenuhan kelengkapan pengembangan organisasi terlebih dahulu. Setelah hal tersebut dipenuhi, langkah selanjutnya adalah penerapan manajemen zero dalam setiap pemberian pelayanan publik kepada masyarakat maupun dalam aktivitas kerja organisasi. Dikaitkan dengan kata kunci yang disampaikan oleh wakil presiden tersebut diatas, maka kata kunci tersebut sangat aplikatif dan terutama berkaitan dengan pelayanan publik.

- Decentralization approach, desentralisasi sebagian tugas instansi kepada unit-unit penyedia pelayanan publik adalah hal mutlak yang perlu dilakukan untuk mempercepat dan memudahkan proses pelayanan kepada masyarakat, dan kondisi ini telah dilakukan oleh sebagian besar instansi induk kepada unit-unit pelayanan yang dimiliki;

- Unit pelayanan publik dapat memilih titik tolak dan menentukan kecepatannya, hal ini juga telah berjalan di beberapa daerah dan telah melahirkan berbagai macam inovasi pelayanan publik yang patut ditiru oleh daerah-daerah lainnya;

- Koordinasi secara sentral, hal ini penting agar tujuan dan arah organisasi yang telah ditetapkan dapat berjalan sempurna ditingkat unit pelayanan publik; dan terakhir adalah outcome oriented, hal ini berjalan melalui penerapan 
manajemen zero oleh unit pelayanan publik mulai dari perencanaan hingga output pelayanan yang diberikan kepada masyarakat sebagai cerminan orientasi kepuasan masyarakat.

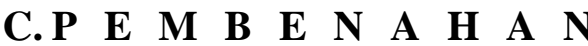 MANAJEMEN PELAYANAN PUBLIK}

Pelayanan publik pada dasarnya adalah sebuah kegiatan atau rangkaian kegiatan dalam rangka memenuhi kebutuhan dasar sesuai dengan hak-hak sipil setiap warga negara dan penduduk atas barang, jasa dan atau pelayanan administrasi yang diselenggarakan oleh penyelenggara pelayanan publik dalam hal ini adalah pemerintah, baik pemerintah pusat/pemerintah daerah maupun BUMN/ BUMD (LAN, 2006)

Pelayanan publik sebagai muara dari pelaksanaan good governance dan indikator kinerja pemerintah dalam rangka memenuhi hak kebutuhan publik, perlu dilengkapi dengan manajemen pelayanan yang optimal. Manajemen pelayanan pada dasarnya adalah upaya internal organisasi penyedia pelayanan publik untuk melakukan perbaikan secara terus menerus (continous improvement) terhadap kualitas pelayanan yang diberikan sesuai tuntutan perubahan yang terjadi, terutama dari lingkungan eksternal organisasi. Berikut upaya pembenahan manajemen pelayanan yang perlu dipenuhi oleh setiap unit pelayanan publik:

\section{Mewujudkan Pelayanan Prima}

Pelayanan prima merupakan suatu pelayanan terbaik, melebihi, melampaui, mengungguli pelayanan yang diberikan pihak lain atau daripada pelayanan waktu sebelumnya. Pelayanan prima atau "excellent service" adalah suatu sikap atau cara karyawan dalam melayani pelanggan secara memuaskan. Dengan kata lain, pelayanan prima adalah pelayanan yang diberikan melebihi harapan pelanggan. Dalam Kepmenpan No. 63 Tahun 2003 tentang Pedoman Umum Penyelenggaraan Pelayanan Publik juga disebutkan bahwa hakekat pelayanan publik adalah pemberian pelayanan prima kepada masyarakat yang merupakan perwujudan kewajiban aparatur pemerintah sebagai abdi masyarakat. Oleh karenanya, kepuasan pelanggan adalah jargon utama yang mendasari dan wajib dipegang teguh petugas pelaksana pelayanan publik (excellent service mindset), sehingga mereka akan lebih termotivasi untuk memberikan pelayanan yang prima. Dwiyanto (2006) mengatakan bahwa kepuasan total dari masyarakat pengguna layanan dapat dicapai apabila birokrasi pelayanan menempatkan masyarakat sebagai pengguna jasa dalam pemberian pelayanan, sehingga paradigma pelayanan publik diarahkan pada perwujudan kualitas pelayanan prima kepada publik melalui instrumen pelayanan yang memiliki orientasi pelayanan yang lebih cepat, lebih baik, dan lebih murah.

Untuk mengoperasionalkan pelayanan prima tersebut sangat bergantung kepada 3P yaitu people, process, dan product. People (frontliner), sebagai garda terdepan 
yang langsung berhubungan dan melaksanakan pelayanan kepada masyarakat harus mampu menunjukkan sikap positif, rasa tanggung jawab, dan jiwa keprofesionalannya dalam bertugas. Memahami secara baik ruang lingkup tugasnya, kompeten, dan mampu melakukan tindakan cepat, tanggap, dan akurat dalam memberikan pelayanan maupun menghadapi permasalahan pelanggan.

Proses pelaksanaan pelayanan publik sebaiknya telah terstandarkan dan dilalui melalui mekanisme penyusunan Standard Operating Procedure (SOP) pada semua aktivitas layanan yang diselenggarakan. SOP secara sederhana diartikan sebagai pedoman atau instruksi tertulis yang menunjukkan apa yang harus dilakukan, kapan hal tersebut dilakukan, dimana dilakukan, dan siapa yang melakukan, sehingga dalam pelaksanaan tugas tidak ada keterlambatan, tidak ada saling menunggu, tidak saling tumpang tindih, tidak saling serobot, dan sebagainya. Pedoman penyusunan SOP ini dapat mengacu pada Permenpan No. PER / 21 / M.PAN / 11/2009 Tentang Pedoman Penyusunan Standar Operasional Prosedur (SOP) Administrasi Pemerintahan. Selain SOP, pelaksanaan pelayanan publik juga perlu dilengkapi Standar Pelayanan (SP) bagi petugas pelayanan sehingga proses pelayanan publik dapat berjalan lebih efektif dan efisien, serta didukung penggunaan IT serta kerjasama petugas pelayanan yang solid (excellent team work and process). Terhadap produk yang dihasilkan, dalam kerangka pelayanan prima adalah selesainya pelayanan mampu lebih cepat dari waktu standar yang telah ditentukan, produk yang dihasilkan berkualitas/ rapi (tidak asal-asalan), lengkap, serta tidak menimbulkan komplain (excellent product).

Selain itu, pelayanan publik yang prima juga perlu dilengkapi dengan layanan pelengkap yang dikhususkan bagi kemudahan dan kepuasan pelanggan selama proses layanan publik berlangsung. Lovelock (1994) dalam Tjiptono (2005) mengklasifikasikan layanan pelengkap menjadi 8 (delapan) kelompok, yaitu :

a. Informasi, misalnya jalan/arah petunjuk menuju lokasi, jadwal penyampaian produk/ jasa, harga, peringatan, kondisi penjualan/ layanan, dokumentasi, tanda terima, dan tiket;

b. Konsultasi, seperti pemberian saran, auditing, konseling pribadi, dan konsultasi manajemen/teknis;

c. Order taking, meliputi aplikasi atau pendaftaran, jasa berbasis kualifikasi, order entry, dan reservasi (tempat duduk, ruangan, professional appiontments);

d. Hospitality, diantaranya sambutan, food and beverages, toilet, dan kamar kecil, fasilitas menunggu (majalah, hiburan, koran, ruang tunggu), transportasi, dan security;

e. Caretaking, terdiri dari perhatian dan perlindungan atas barang 
milik pelanggan yang mereka bawa (parkir kendaraan roda dua dan roda empat, penanganan bagasi, titipan tas), serta perhatian dan perlindungan atas barang yang dibeli pelanggan (pengemasan, transportasi, pengantaran, instalasi, pembersihan, inspeksi dan diagnosis, pemeliharaan preventif, reparasi dan inovasi, upgrades);

f. Exceptions, meliputi permintaan khusus sebelum penyampaian produk, menangani komplain/ pujian/ saran, pemecahan masalah (jaminan dan garansi atas kegagalan pemakaian produk, kesulitan yang muncul dari pemakaian prroduk atau disebabkan kegagalan produk), dan restitusi (pengembalian uang, kompensasi);

g. Billing, yaitu laporan rekening, atau faktur untuk transaksi individual, dan self billing;

h. Pembayaran, berupa pelanggan berinteraksi dengan petugas yang menerima pembayaran, serta konrol dan verifikasi.

\section{Memiliki Standar Pelayanan}

$\mathrm{D}$ a $1 \mathrm{a} \mathrm{m} \quad \mathrm{K}$ e $\mathrm{m}$ e $\mathrm{n} \mathrm{p}$ a $\mathrm{n}$ No.63/KEP/M.PAN/7/2003 Tentang Pedoman Umum Penyelenggaraan Pelayanan Publik menegaskan bahwa setiap penyelenggaraan pelayanan publik harus memiliki standar pelayanan dan dipublikasikan sebagai jaminan adanya kepastian bagi penerima pelayanan. Standar pelayanan publik sesuai Permenpan No. PER/20/M.PAN/04/2006 Tentang Pedoman Penyusunan Standar
Pelayanan Publik merupakan suatu tolok ukur yang dipergunakan sebagai pedoman penyelenggaraan pelayanan dan acuan penilaian kualitas pelayanan sebagai komitmen atau janji dari penyelenggara pelayanan kepada masyarakat untuk memberikan pelayanan yang berkualitas. Komponen standar pelayanan publik, sekurang-kurangnya meliputi :

a. Jenis Pelayanan

Pelayanan-pelayanan yang dihasilkan oleh unit penyelenggara pelayanan.

b. Dasar Hukum Pelayanan

Peraturan perundang-undangan y a n g m e n jadi d a s a r penyelenggaraan pelayanan.

c. Persyaratan Pelayanan Syarat-syarat yang harus dipenuhi dalam pengurusan sesuatu jenis pelayanan, baik persyaratan teknis maupun administratif.

d. Prosedur Pelayanan

Tata cara pelayanan yang dilakukan bagi pemberi dan penerima pelayanan termasuk pengaduan.

e. Waktu penyelesaian Pelayanan Jangka waktu yang diperlukan untuk menyelesaikan seluruh proses pelayanan dari setiap jenis pelayanan.

f. Biaya pelayanan

Besaran biaya/ tarif pelayanan yang harus dibayarkan oleh penerima pelayanan.

g. Produk pelayanan

Hasil pelayanan yang akan diterima sesuai dengan ketentuan yang telah ditetapkan.

h. Sarana dan Prasarana 
Fasilitas yang diperlukan dalam penyelenggaraan pelayanan, termasuk fasilitas pelayanan bagi penyandang cacat.

i. Mekanisme Penanganan Pengaduan

Tata cara pelaksanaan penanganan pengaduan sesuai dengan ketentuan yang berlaku.

Selain komponen tersebut di atas, dalam penyusunan standar pelayanan perlu memperhatikan faktor pendukung antara lain :

a. Kompetensi petugas pemberi pelayanan

Kompetensi petugas pemberi pelayanan harus ditetapkan dengan tepat berdasarkan pengetahuan, keahlian, keterampilan, sikap, dan perilaku yang dibutuhkan.

b. Mekanisme Pengawasan

Tata cara pelaksanaan pengawasan sesuai dengan ketentuan yang berlaku

Penetapan standar pelayanan merupakan proses yang tidak hanya akan memberikan informasi mengenai standar pelayanan yang harus ditetapkan tetapi juga informasi mengenai kelembagaan yang mampu mendukung terselenggaranya proses manajemen yang menghasilkan pelayanan sesuai standar yang telah ditetapkan. Informasi lain yang juga dihasilkan adalah informasi mengenai kuantitas dan kompetensi-kompetensi sumberdaya manusia yang dibutuhkan serta distribusinya beban tugas pelayanan yang akan ditanganinya (Fanar Syukri, 2009).

\section{Managing Costumer Service and Ethics}

Penyedia dan penyelenggara pelayanan publik harus memiliki kemampuan dan keterampilan melayani (quality service), mengetahui trik menghadapi pelanggan, serta memahami langkah-langkah pemulihan (service breakdown). Karakteristik sikap, perilaku, maupun latar belakang pelanggan tentunya beraneka ragam, yang berarti teknik penanganannya pun berbeda-beda. Oleh karenanya, kemampuan mengendalikan diri (baik emosi maupun psikis) yang digunakan dan diaplikasikan dalam bentuk sapaan; mengenali dan menawarkan bantuan; mendengarkan dengan aktif dan memberikan tanggapan dengan empati; memastikan kepuasan pelanggan; meningkatkan harga diri pelanggan; dan mengakhiri dengan ucapan terimakasih dan kesediaan melayani dimasa mendatang.

Etika pelayanan juga perlu dipahami oleh petugas layanan, mulai dari cara berpakaian, penampilan, cara berjalan, cara melayani, cara berbicara, kesehatan pribadi, gesture tubuh dan mimik wajah. Kesemua hal tersebut sangat penting sebagai bagian dari pencitraan dan penunjang pelayanan prima, seperti kata Finch (2004) bahwa manajemen diri petugas pelayanan yang berhasil termasuk merawat diri dan berbusana dengan profesional, anda (petugas pelayanan) bertanggung jawab untuk menunjukkan kesan yang profesional bahkan ketika 
anda sedang tidak bertatap muka dengan pelanggan. Memahami e tik a pelay a n a d a n mengaplikasikannya secara baik akan memudahkan petugas layanan untuk mendekatkan diri kepada pelanggan.

\section{Menerapkan Budaya Pelayanan}

Kinerja pelayanan publik yang prima tentunya bergantung kepada kemampuan optimal para petugas layanan. Oleh karenanya, semangat dan kekompakan tim harus mampu ditimbulkan dan dipelihara demi menjaga ritme kerja yang baik secara berkelanjutan. Berbagai cara yang dapat dilakukan diantaranya, mengadakan coffee morning atau pertemuan dengan seluruh pimpinan dan pegawai secara reguler yang dilaksanakan secara santai/nonformal untuk memecahkan persoalan yang timbul seputar pelaksanaan tugas; melaksanakan pelatihan-pelatihan building spirit, building team-work, building emphaty, building trust and belief, building relationship, building service culture-set, dan lain-lain yang intinya mampu menguatkan kebersamaan tim dalam memberikan pelayanan prima kepada pelanggan.

\section{Review Kinerja Berbasis Partisipasi Masyarakat Pengguna Layanan}

Un t u k m e m a s tikan pembenahan manajemen pelayanan apakah berjalan dengan baik serta berdampak pada kepuasan masyarakat, perlu dilakukan review dan evaluasi atas kinerja organisasi dengan melibatkan masyarakat pengguna layanan. Berbagai macam instrumen pengukuran dapat digunakan, salah satunya adalah penggunaan Kepmenpan No: KEP/ 25/M.PAN/2/2004 tentang Pedoman Umum Penyusunan Indeks Kepuasan Masyarakat (IKM) Unit Pelayanan Instansi Pemerintah. Melalui pengukuran IKM tersebut akan diketahui perkembangan kinerja unit pelayanan publik secara berkala sebagai bahan untuk menetapkan kebijakan dalam rangka peningkatan kualitas pelayanan publik selanjutnya.

Selain itu, juga dapat digunakan Permenpan No. 13 Tahun 2009 Tentang Pedoman Peningkatan Kualitas Pelayanan Publik dengan Partisipasi Masyarakat, dimana didalamnya tersedia metode peningkatan kualitas pelayanan publik berbasis partisipasi masyarakat. Metode tersebut dimulai dari pengelolaan pengaduan masyarakat pengguna pelayanan sebagai dasar awalan (orientasi), merumuskan tindakan nyata pebaikan pelayanan, memantau dan mengevaluasi keberhasilan, dan mengkomunikasikannya kepada masyarakat pengguna layanan. Keseluruhan metode tersebut dilakukan dengan instrumen sederhana, dapat dilakukan dengan biaya murah, dan dalam waktu relatif singkat mampu memandu penyelenggara dan pelaksana pelayanan publik melakukan tindakan nyata perbaikan pelayanan. 
Untuk organisasi pelayanan publik, informasi mengenai kinerja tentu sangat berguna untuk menilai seberapa jauh pelayanan yang diberikan oleh organisasi itu memenuhi harapan dan memuaskan pengguna jasa. Dengan melakukan penilaian terhadap kinerja, maka upaya untuk memperbaiki kinerja bisa dilakukan secara lebih terarah dan sistematis. Informasi mengenai kinerja juga penting untuk menciptakan tekanan bagi para pejabat penyelenggara pelayanan untuk melakukan perubahanperubahan dalam organisasi. Dengan adanya informasi mengenai kinerja, maka benchmarking dengan mudah bisa dilakukan dan dorongan untuk memperbaiki kinerja bisa diciptakan (Dwiyanto, 2006).

\section{D.Pemenuhan Kelengkapan Pengembangan Organisasi}

Pelayanan publik dengan manajemen pelayanan yang prima hanya dapat tercapai jika didukung dengan ketersediaan daya dukung pengembangan organisasi berupa sumberdaya organisasi yang mumpuni, ditambah komitmen pimpinan yang serius dan concern dalam peningkatan kualitas pelayanan publik. Berikut secara rinci upaya pemenuhan kebutuhan pengembangan unit pelayanan publik:

\section{Pemanfaatan ICT}

Pengembangan e-government, termasuk e-service yang saat ini gencar didorong telah membawa masyarakat kepada pelayanan yang lebih cepat, modern, dan mudah. Masyarakat juga semakin mudah menyampaikan keluhannya dengan memanfaatkan media SMS, hotline pengaduan, website dan juga $e$-mail. Oleh karenanya, pengembangan dan pemanfaatan ICT dalam pekerjaan unit pelayanan publik perlu terus diupayakan sebagai bagian dari penyederhanaan prosedur dan mekanisme kerja pelayanan publik. Salah satu tujuan implementasi e-government adalah agar lembaga-lembaga pemerintah mampu menyediakan layanan publik yang baik sehingga dapat semakin transparan, semakin bersih, dan semakin akuntabel (warta ekonomi, 2010).

\section{Dukungan Sarana dan Prasarana}

Pemenuhan ketersediaan sarana dan prasarana penunjang tugas juga perlu dilakukan unit pelayanan publik guna memperlancar proses kerja berjalan. Sesuai dengan tugasnya yang bersifat teknis dan operasional, maka keterhubungan pelayanan publik dengan sarana dan prasarana kerja yang lengkap, cukup erat dan akan saling mempengaruhi terhadap keberhasilan pencapaian kerja pelayanan publik yang berkualitas dan prima.

\section{Dukungan SDM Pelayan Publik yang Handal}

Kebutuhan akan jumlah dan kualitas SDM yang berkompeten diperlukan guna menutupi celah beban kerja organisasi serta tuntutan perkembangan zaman (termasuk tuntutan masyarakat). Pengembangan jumlah SDM dapat dipenuhi melalui upaya rekrutmen pegawai sesuai hasil analisis jabatan yang dilakukan, sehingga SDM 
yang direkrut betul-betul sesuai dengan kebutuhan organisasi. Sedangkan pengembangan kualitas SDM ditempuh melalui upaya pendidikan dan pengiriman pegawai untuk mengikuti pelatihanpelatihan teknis dan fungsional sesuai lingkup tugas unit pelayanan publik. Perlu dipahami bahwa kesiapan petugas pelayanan ditingkat bawah merupakan hal yang sangat penting, dan sebagai pintu pertama pelayanan, penyortir beneficiary, bahkan penentu masyarakat yang dilayani, dan akhirnya menentukan mutu pelayanan yang diberikan.

\section{Dukungan serta Komitmen dari Pimpinan dan Segenap Pegawai}

Mewujudkan kepuasan masyarakat, menerapkan pelayanan prima, melaksanakan pelayanan terpadu, dan jargon-jargon pelayanan publik lainnya, akan menjadi sekedar konsep belaka jika tidak didukung sepenuhnya oleh pimpinan daerah dan pimpinan unit pelayanan publik yang secara serius $\mathrm{d}$ a $\mathrm{n}$ a $\mathrm{ntu}$ s i a s d a $1 \mathrm{a} \mathrm{m}$ mewujudkannya. Peran penting pimpinan akan sangat menentukan keberhasilan peningkatan kualitas pelayanan publik, sebab pimpinan melalui otoritas dan kewenangan yang dimiliki dapat mengarahkan, mengingatkan, dan mendorong segenap sumberdaya yang ada untuk mendukung kualitas pelayanan publik yang semakin baik. Jika komitmen dan perhatian pimpinan cukup besar, maka perlu didukung pula oleh komitmen bersama segenap komponen yang terlibat untuk secara bersama-sama dan bahu membahu melaksanakan pelayanan publik yang prima kepada masyarakat.

\section{E. MANAJEMEN ZERO}

Pemberlakuan Manajemen zero dalam pelaksanaan tugas unit pelayanan publik sangat baik dalam rangka menghasilkan output kerja yang berkualitas. Manajemen zero menurut penulis adalah tatakelola pelaksanaan organisasi dengan mengedepankan tidak adanya kesalahan ataupun kekurangan dari suatu siklus pekerjaan mulai dari awal hingga akhir. Manajemen zero tidaklah sepenuhnya harus tidak ada salah, atau tidak ada kekurangan, namun manajemen zero sebenarnya adalah sebuah grafik menurun dari jumlah kesalahan atau kekurangan dalam suatu siklus pekerjaan dari waktu ke waktu hingga mendekati angka nol (zero). Manajemen zero memang ekstrim, namun cukup baik dalam rangka mempertahankan mutu dan kualitas produksi. Oleh karenanya, pengaplikasiannya dalam lingkup pelayanan publik instansi pemerintah membutuhkan waktu yang bertahap/ secara gradual hingga dapat diterapkan secara utuh.

Manajemen zero dalam pelayanan publik dapat diwujudkan dalam bentuk, zero defect (tidak ada cacat), bahwa produk pelayanan publik harus berkualitas tinggi dan sesuai standar sehingga tidak ditemukan kesalahan-kesalahan yang menimbulkan kecacatan dari suatu produk pelayanan publik seperti kualitas cetakan yang buram, sobek, terpotong, tidak terbaca, atau mudah terlepas; zero accident (tidak ada 
kecelakaan), bahwa dalam pelaksanaan pelayanan publik berpegang teguh pada standar pelayanan maupun standar operasional prosedur yang telah ditetapkan, sehingga tindakantindakan yang tidak perlu dan membahayakan tidak terjadi, serta tetap mengutamakan keselamatan bersama baik pelanggan maupun petugas; zero add cost (tidak ada penambahan biaya), bahwa agar proses pelayanan publik dapat berjalan optimal, harus sesuai dengan perencanaan yang telah ditetapkan serta ketentuan yang berlaku; zero delay (tidak ada keterlambatan), bahwa dalam penyelenggaraan pelayanan publik mulai dari proses pendaftaran hingga selesainya layanan harus sesuai dan tepat dengan jangka waktu waktu yang telah ditetapkan, bahkan diupayakan agar bisa lebih cepat; bahkan hingga kepada zero complain (tidak ada keluhan), yaitu kondisi dimana pelayanan publik yang diberikan sangat memuaskan dan berkualitas, sehingga tidak ada lagi komplain, ketidaksenangan, atau ketidaknyamanan yang dirasakan oleh pelanggan.

Ketika keseluruhan mekanisme tersebut (pembenahan manajemen pelayanan, dukungan pengembangan organisasi, serta penerapan manajemen zero) mampu berjalan optimal dan berkesinambungan, disertai review kinerja penyelenggaraan pelayanan publik secara reguler, maka reformasi birokrasi dapat dikatakan berhasil. Keberhasilan pelaksanaan reformasi birokrasi disebabkan karena telah terjadi perubahan dalam manajemen pemerintahan, dari yang sifatnya bureaucratic monopolistic ke arah entrepreunerial compettitive; dari yang unresponsive menjadi responsive; dari yang bersifat local orientation ke arah global orientation, bahkan bisa jadi berorientasi cosmopolit.

\section{F. OTONOMI DAERAH DAN PELAYANAN PUBLIK}

Kondisi saat ini menunjukkan bahwa masyarakat masih menghadapi ketidakpastian dalam memperoleh pelayanan terutama terhadap layanan hak warga negara dimana masyarakat cenderung dalam posisi tawar yang lemah, dominasi pemerintah untuk melakukan kehendaknya sangat tinggi, apalagi saat ini masih banyak unit pelayanan yang belum memiliki standar pelayanan. Kondisi inilah yang terkadang memberikan peluang terjadinya KKN.

Otonomi daerah yang telah berjalan 12 tahun ternyata memiliki korelasi positif terhadap peningkatan pelayanan publik dan kesejahteraan masyarakat, sebab melalui otonomi daerah pemerintah daerah lebih memiliki kemampuan dan berhak mengatur, merancang, dan menentukan sendiri upaya-upaya peningkatan kualitas pelayanan publik di daerahnya serta peningkatan kesejahteraan masyarakatnya sebab itulah inti dan filosofi dasar otonomi daerah digulirkan. Jika kemudian pelayanan publik dan kesejahteraan masyarakat tidak semakin baik, berarti ada kesalahan dalam menafsirkan dan menjalankan otonomi daerah. Dwiyanto (2006) menambahkan bahwa birokrasi yang memiliki kinerja buruk dalam memberikan pelayanan publik akan sangat mempengaruhi kinerja pemerintahan dan masyarakat 
secara keseluruhan dalam rangka meningkatkan daya saing daerah. Oleh karenanya, otonomi daerah perlu dikawal oleh seluruh pihak untuk menjamin tercapainya pelayanan publik dan kesejahteraan masyarakat yang lebih baik.

Pelayanan publik di era otonomi daerah sangat baik dibanding era sentralisasi sebelumnya, bahkan banyak pemerintah daerah yang telah menelurkan inovasi dan kreativitas sehingga menjadi contoh dan direplikasikan didaerah-daerah lainnya (best practices). Pemerintah juga memberikan award kepada daerahdaerah yang mampu memberikan terobosan pada peningkatan kualitas pelayanan publik melalui Pemberian Penghargaan Citra Pelayanan Prima (CPP), Penghargaan E-Government Award, serta Penghargaan Innovative Government Award (IGA). Khusus IGA tahun 2010 ini terbagi atas 5 (lima) kategori yang salah satunya adalah kategori pelayanan publik yang dimenangkan oleh Kota Surakarta melalui Program Tri Krida Utama yaitu terobosan penataan lingkungan kota yang mempercantik wajah kota demi mencapai tujuan kota Budaya, Kota Pariwisata dan Kota Olahraga; Kota Palangkaraya dengan Pelayanan Kesehatan Lansia dan Radio Medik; dan Kota Sukabumi melalui program Integrasi Pengelolaan Sampah Dengan Penggemukan Sapi Dan Padi Organik.

Terkait dengan IGA tahun 2010 terdapat kategori lainnya yang terkait dengan peningkatan kualitas pelayanan publik, yaitu kategori inovasi berkelanjutan yang dimenangkan oleh Kabupaten Sragen, melalui inovasi
Technopark (Technopark Ganesha Sukowati Sragen) yaitu suatu kawasan pusat pelatihan teknologi; Kabupaten Kutai Timur, melalui inovasi sistem insentif guru berdasarkan zona keterjangkauan dan melalui pengembangan Forum Multi Stake Holder (FMS); dan Kota Batam, dengan inovasi Sistem Pelayanan Informasi dan Perizinan Investasi Secara Elektronik (SPIPISE) untuk aplikasi lebih maju di Pelayanan Terpadu Satu Pintu (PTSP).

Contoh lain praktik-praktik terbaik (best practices) pelayanan publik yang telah banyak direplikasi atau diduplikasi oleh daerah-daerah lain diantaranya: Kabupaten Bulukumba, dengan penerapan model voucher pelayanan kebidanan; Provinsi Kalimantan Timur, berupa pengisian formasi jabatan eselon II secara terbuka dan kompetitif (competitive leadership inventory); Kota Tarakan, yang berusaha merangsang pertumbuhan ekonomi dan Pendapatan Asli Daerah (PAD) tanpa membebani masyarakat; Kota Banjarmasin, yang menerapkan prinsip pembelajaran dalam organisasi pelayanan air bersih; Kota Palangkaraya, yang berhasil mendongkrak kualitas pelayanan bidang kesehatan dengan pola swadana; Kota Pontianak, yang menonjolkan pemanfaatan produk lokal unggulan yaitu lidah buaya (Aloe Vera), dan penerapan mekanisme pembangunan bersih (MPB) dalam pengelolaan sampah. Dengan replikasi diharapkan terjadi reformasi pelaksanaan tata pemerintahan daerah yang baik lebih meluas. Akselerasi yang terjadi pada proses replikasi ini 
juga tidak semahal bila melakukan perubahan yang dimulai dari nol. Kemungkinan sukses replikasi pun lebih besar ketimbang melakukan sebuah inisiatif tanpa referensi sama sekali (Eko Susi, 2007).

Upaya benchmarking terhadap daerah atau instansi yang telah menunjukkan keberhasilan dalam bidang tertentu perlu pula dilakukan. Hal ini bukan dimaksudkan untuk membudayakan kebiasaan meniru, $\mathrm{n}$ a mun semata-mata demi mempercepat proses perubahan dan kemajuan bagi suatu daerah/ instansi yang bersangkutan. Dengan adanya identifikasi dan diseminasi best practice, diharapkan akan dicapai kegunaannya paling tidak mencakup 3 dimensi (BKDTarakan, 2007) :

1. Untuk memotivasi dan mengapresiasi para pejabat dan anggota masyarakat di daerah yang b e r s a n g k t a n un tu k mengimplementasikan best practice yang telah dihasilkan serta u n u k me ng gali d a n mengembangkan best practice lainnya;

2. Untuk membangkitkan semangat berkompetisi daerah atau instansi lainnya untuk melakukan hal yang sama;

3. Untuk mengakselerasi kinerja pemerintah daerah dalam bidang pembangunan dan pelayanan

Berpijak pada kemampuan dan capaian tersebut, pemerintah baik pusat maupun pemerintah daerah terus berupaya mewujudkan pelayanan publik yang semakin baik setiap harinya. Bahkan perlu segera mempersiapkan diri untuk menuju pada pelayanan publik yang lebih transparan dan lebih akuntabel sebagai bagian dari pelaksanaan good governance. Transparan berarti terbuka bagi masyarakat dari proses kebijakan, perencanaan, pelaksanaan, dan pengawasan, serta mudah diakses oleh semua pihak yang membutuhkan informasi terutama yang terkait dengan:

- Manajemen dan penyelenggaraan (menyangkut kebijakan, perencanaan, pelaksanaan, pengawasan/pengendalian, serta informasi)

- Prosedur (sederhana, tidak berbelit, jelas, mudah dipahami dan dilaksanakan, dipublikasikan dengan bagan alir)

- Persyaratan (teknis administratif) menyangkut relevansi, disusun sederhana dan seminimal mungkin, tidak duplikasi, serta di informasikan dengan jelas)

- Biaya (memperhatikan kemampuan masyarakat, dan dilengkapi dengan tanda bukti)

- Waktu penyelesaian (jelas mulai dari permohonan sampai selesai, diberi nomor urut, serta diinformasikan dengan jelas)

- Pejabat yang berwenang atau bertanggungjawab (menyelesaikan pengaduan, memakai tanda pengenal, surat tugas, memiliki sikap sopan ramah empati, dan mengetahui apa yang dibutuhkan)

- Lokasi (mudah dijangkau, tetap/ tidak berpindah-pindah, dilengkapi sarana dan prasarana yang cukup)

- Janji pelayanan (komitmen tertulis dalam pelayanan, ditulis jelas singkat mudah dipahami, termasuk mengenai standar, dapat pula dibuat "motto pelayanan" yang bersifat 
memberi semangat atau motivasi)

- Standar pelayanan (berisi ukuran kinerja yang dibakukan, harus ditaati oleh pemberi/ penerima pelayanan, realistis, jelas dan mudah dimengerti)

- Informasi pela y a n a n, dipublikasikan dengan baik melalui media cetak/elektronik atau penyuluhan (berisi prosedur, persyaratan, biaya, waktu, standar, janji, motto pelayanan, lokasi serta pejabat/ petugas yang berwenang dan bertanggung jawab).

A kuntabilitas dalam penyelenggaraan pelayanan publik menurut Dwiyanto (2006) adalah suatu ukuran yang menunjukkan seberapa besar tingkat kesesuaian penyelenggaraan pelayanan dengan ukuran nilai-nilai atau norma eksternal yang ada di masyarakat atau yang dimiliki oleh para stakeholders. Nilai dan norma pelayanan yang berkembang dalam masyarakat tersebut, diantaranya meliput, transparansi pelayanan, prinsip keadilan, jaminan penegakan hukum, hak asasi manusia, dan orientasi pelayanan yang dikembangkan terhadap masyarakat pengguna jasa. Secara ringkas penulis rumuskan bahwa penyelenggaraan pelayanan publik yang akuntabel berarti penyelenggaraan pelayanan harus dapat dipertanggungjawabkan, baik kepada publik maupun kepada atasan/ pimpinan unit pelayanan instansi pemerintah sesuai dengan ketentuan peraturan perundang-undangan, yang berupa :

- Akuntabilitas kinerja, menyangkut ketelitian; profesionalitas; kelengkapan sarana dan prasarana; kejelasan aturan; kedisiplinan; sesuai standar; terbuka; dan $\mathrm{t}$ e r d a a t m e kan i s m e pertanggungjawaban.

- Akuntabilitas biaya, bahwa antara biaya yang telah ditetapkan dan pemberlakuannya sesuai ketentuan.

- Akuntabilitas produk, yaitu output layanan publik tersebut benar, tepat, dan sah.

\section{G.PENUTUP}

Membenahi dan terus-menerus melakukan perbaikan atas pelayanan publik adalah cerminan pelaksanaan tatakelola pemerintahan yang baik dan bermutu. Sangat diperlukan komitmen penuh dari pimpinan dengan menjadi sumber inovasi dan panutan, pengarah, dan pengambil inisiatif dalam rangka mendorong pelayanan publik yang lebih baik dan maju. Pemerintah pusat maupun pemerintah daerah juga perlu lebih mendorong kompetisi pelayanan publik bagi seluruh penyelenggara pelayanan publik melalui pemberian insentive khusus serta penghargaan lainnya (awards). Mencapai kepuasan masyarakat adalah idaman setiap pemerintah, oleh karenanya masyarakat perlu ditempatkan pada posisi yang diprioritaskan/ didahulukan melalui upaya pemberian pelayanan yang prima, sebab "with service excellence, everybody wins".

\section{DAFTAR PUSTAKA}

Badan Kepegawaian Daerah Kota Tarakan, 2007. Membangun Sistem Informasi Manajemen Kepegawaian (SIMPEG) Secara Mandiri : Dokumentasi Best Practice di BKD Kota 
Tarakan. Tarakan: Badan Kepegawaian Daerah.

Boediono, 2010. Empat Kata Kunci Reformasi Birokrasi. dalam www.menpan.go.id. diakses pada tanggal 19 Desember 2010

Dwiyanto, Agus., dkk, 2006. Reformasi Birokrasi Publik di Indonesia. Yogyakarta: Gadjah Mada University Press.

Eko Susi R., 2007. Best Practices: Upaya Kreatif Pelaksanaan Good Governance http://www.yipd.or.id., diakses tanggal 15 Mei 2010.

Fanar Syukri, Agus. 2009. Standar Manajemen Mutu Pelayanan Publik Pemerintah Daerah. Makalah Disajikan dalam Seminar Berjudul Reformasi Birokrasi di PKP2A III LAN Samarinda.

Finch, Lloyd., 2004. Menjadi Costumer Service Representative Yang Sukses. Jakarta: Penerbit PPM.

Lembaga Administrasi Negara, 2006. Strategi Peningkatan Kualitas Pelayanan Publik. Jakarta: LAN

Menteri Negara Pendayagunaan Aparatur Negara dan Reformasi Birokrasi, 2010. A $r a h \quad K e b i j a k a n$ Pendayagunaan Aparatur Negara dan Percepatan Pelaksanaan Reformasi
Birokrasi. M a kalah disampaikan dalam Rapat Koordinasi Pendayagunaan Aparatur Negara-Tingkat Nasional Tanggal 23-24 November 2010, Jakarta

Tjiptono, Fandy., 2005. PrinsipPrinsip Total Quality Service (TQS). Yogyakarta: Penerbit Andi Offset.

Keputusan Menteri Pendayagunaan A $\mathrm{p} \mathrm{a} \mathrm{rat} u \mathrm{r}$ e g a $\mathrm{ra}$ No:KEP/63/M.PAN/7/2003 tentang Pedoman Umum Penyelenggaraan Pelayanan Publik

Keputusan Menteri Pendayagunaan Aparatur Negara No: KEP/ 25/ M.PAN/ 2/ 2004 tentang Pedoman Umum Penyusunan Indeks Kepuasan Masyarakat (IKM) Unit Pelayanan Instansi Pemerintah

Peraturan Presiden No. 5 Tahun 2010 $\mathrm{t}$ e n t a $\mathrm{g} \quad R$ e $n$ c a n a Pembangunan Jangka Menengah Nasional tahun 2010-2014

Peraturan Menteri Negara Pendayagunaan Aparatur Negara No. PER / 20 / M.PAN / 04/2006 tentang Pedoman Penyusunan Standar Pelayanan Publik

Peraturan Menteri Negara Pendayagunaan Aparatur Negara No:PER / 15 / M.PAN / 7/2008 tentang Pedoman Umum Reformasi Birokrasi 
Peraturan Menteri Negara Pendayagunaan Aparatur Negara No. PER / 21 / M.PAN / $11 / 2009$ tentang Pedoman Penyusunan Standar Operasional Prosedur (SOP) Administrasi Pemerintahan

Permenpan No. 13 Tahun 2009 tentang Pedoman Peningkatan Kualitas Pelayanan Publik dengan Partisipasi Masyarakat

Rhenald Kasali, 2007. Change : Tak Peduli Berapa Jauh Jalan Salah Yang Anda Jalani, Putar Arah Sekarang Juga
(Manajemen Perubahan dan Manajemen Harapan). Jakarta: Gramedia Pustaka Utama.

Ridwan HR, 2008. Hukum Administrasi Negara. Jakarta: Raja Grafindo Persada.

Warta Ekonomi, 2010. AplikasiAplikasi E-Government Unggulan (E-Government Award 2009). Jakarta: Jakarta

Zeithaml, Parasuraman, dan Berry., 1990. Delivering Quality Service : Balancing Customer Perceptions and Expectations. New York: The Free Press.

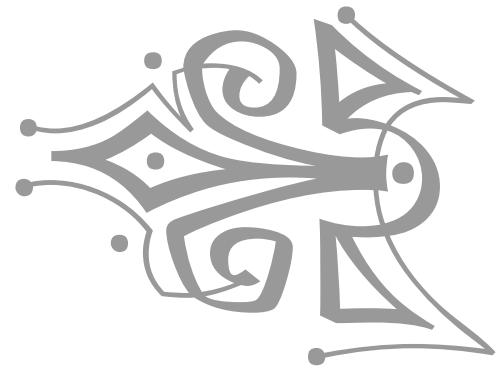

